\title{
Trickle-Down Democracy: \\ The Commission Government Contest in Des Moines, 1905-1908
}

\author{
ROBERT E. BIONAZ
}

\begin{abstract}
"AW, WHAT'S THE USE!" exclaimed the Des Moines Register and Leader's front-page cartoon caption on the morning of March 31, 1908 (see cover). J. N. "Ding" Darling's artistic rendering of the previous day's election results depicted a disconsolate "citizen" - staring morosely at the ground from his seat atop an overturned bucket-contemplating the empty promise of the recent election and Des Moines's grim future. ${ }^{1}$ Darling's artistry captured the bitter disappointment of the elite men and their allies who had led the fight for commission government in Des Moines between 1905 and 1908, and who had just seen the city's voters reject their entire hand-picked and heavily promoted "people's" ticket. Just over nine months earlier, that same group of business and professional leaders had tasted victory when the city's voters approved their plan for a commission government to replace the old mayor and council system. The pleasure those reformers felt in 1907 and the anguish they experienced in 1908 represent two sides of the same coin. Although the commission government drive in Des Moines stemmed from the desire of business and professional elites to create a government responsive to their interests, in the end they got only the system they wanted, not the control they desired through the election of the "right" men.
\end{abstract}

1. Des Moines Register and Leader, 31 March 1908.

THE ANNALS OF IOWA 58 (Summer 1999). (CThe State Historical Society of Iowa, 1999. 
The commission government idea gained momentum during the Progressive Era, as more than 500 cities in 41 states adopted a more centralized form of government between 1907 and 1920. The Des Moines campaign illustrates that such reform could be hotly contested, as reformers and their opponents continued the long-running American debate over who should rule and how. ${ }^{2}$ Pro-commission reformers, many driven as much by the desire to profit from the business opportunities created by an expanding city as by the desire for efficiency, sought to replace the system of ward representation with what they characterized as a more businesslike, efficient, honest, and centralized city government. At meetings and in newspapers, these reformers argued that the public good stemmed from business prosperity: in a thriving city, booming business and population growth created wealth that would trickle down to every resident. These business and professional elites believed that ward democracy frustrated their efforts to stimulate business growth, and prevented their social inferiors from realizing both where their true interests lay and who should properly govern the city. This vision of municipal government differed from the view held by many residents of Des Moines's working-class wards. Led by the city's unions, Des Moines's workers championed a popular democracy that embraced local representation and assailed the autocratic pretensions of the reformers. Their critique forced reformers to defend as well as promote the plan and set the stage for the cross-class alliance that defeated the elite effort to gain control of the city's elective offices.

Pro-commission spokespersons shrouded in the rhetoric of efficiency their desire for elite political control, and they skillfully used the city's press to create an image of existing munici-

2. See Bradley Robert Rice, Progressive Cities: The Commission Government Movement in America, 1901-1920 (Austin, TX, 1977), 110-11, 113-25. Carl V. Harris, Political Power in Birmingham, 1871-1921 (Knoxville, TN, 1984), reveals the relationship between class and political power. Lynette Boney Wrenn, Crisis and Commission Government in Memphis: Elite Rule in a Gilded Age City (Knoxville, TN, 1998), explores the antidemocratic potential of commission government. See also Amy Bridges, Morning Glories: Municipal Reform in the Southwest (Princeton, NJ, 1997); and William Issel, "Class and Ethnic Conflict in San Francisco Political History: The Reform Charter of 1898," Labor History 18 (1977), 341-59. 
pal corruption. However, in response to their opponents' criticism, and in order to maximize their appeal, pro-commission spokespersons had to reformulate their plan to include direct democracy provisions. Although reformers believed that only the right kind of businessmen should control the city's businesslike government, Des Moines's workers fought against "aristocratic" encroachments on their liberties, defended popular democracy, and ultimately rejected the leadership of business interests allied with the city's press. In the end, neither side got exactly what it desired. ${ }^{3}$

THE DISSATISFACTION of the city's business and professional elites with city government manifested itself in the struggle to restructure and reform the municipal government in 1907-8 - an effort that raises the question of why Des Moines's reformers were so discontented with the city's management. Although their rhetoric featured frequent discussions of inefficiency and corruption at City Hall-two evils commission government promised to eliminate-a look at the municipal government's operation in the years just prior to the election of 1907 reveals a picture far different from the one painted by reformers. ${ }^{4}$

3. For contemporary accounts of the commission government phenomena see Ernest S. Bradford, Commission Government in American Cities (New York, 1911); Clinton Rogers Woodruff, City Government by Commission (New York, 1911); William Bennett Munro, The Government of American Cities (New York, 1912); and Charles A. Beard, American City Government: A Survey of Newer Tendencies (New York, 1912). My approach to this topic has been heavily influenced by Samuel P. Hays, "The Politics of Reform in Municipal Government in the Progressive Era," Pacific Northwest Quarterly 55 (1964), 157-69. Hays emphasized the differences between reform ideology and political practice. Locating the source of support for municipal government reform in the upper classes, he argued that reformers sought to limit popular participation in municipal affairs through the installation of a business-controlled city government.

4. Jon Teaford argues that late nineteenth-century municipal governments generally operated efficiently - that they represented "a failure not of structure but of image." Jon C. Teaford, The Unheralded Triumph: City Government in America, 1870-1900 (Baltimore, 1984), 1-11. Compare Robert H. Wiebe, The Search for Order, 1877-1920 (New York, 1967), 112-29; Martin J. Schiesl, The Politics of Efficiency: Municipal Administration and Reform in America, 1800-1920 (Berkeley, CA, 1977), 1-5; James Weinstein, "Organized Business and the City Commissioner and Management Movements," Journal of Southern History 18 (1962), 166-67, 177-81; Richard Hofstadter, The Age of Reform: From Bryan to F.D.R. (New York, 1955), 5. 
Des Moines's population increased by 39 percent between 1900 and 1910, growing from 62,139 to 86,368. In 1907 the Census Bureau estimated the city's population at just over 81,000 . In 1910 the Census Bureau classified 96 percent of the population as ethnically white and 87 percent of the white population as native-born. The majority of the foreign-born population came from northern and western Europe. More than one-quarter of the city's residents were young people between the ages of six and twenty. Ninety percent of children aged six to fourteen attended school. ${ }^{5}$

This stable, family-oriented, rapidly growing population offered opportunities for businessmen to profit, particularly in industries related to the city's growth: banking, insurance, the building trades, and real estate. Indeed, in Des Moines the Commercial Club, an organization of leading business and professional men committed to growth and to "boosting" the city's businesses, consistently stressed the importance of growth in their vision of a "greater" Des Moines. However, these "boosters" found their efforts hamstrung by a city government they described as "Des Moines' worst handicap." ${ }^{\prime 6}$ By the fall of 1905, the city-boosting movement and the effort to change the government's structure had become intertwined.

That fall, attorney, banker, and real estate developer James G. Berryhill returned from a trip to Galveston, Texas, and presented a glowing report on the efficiency of that city's commission government to a group of businessmen described by the Register and Leader as "the brains and financial backbone of the city."

5. Of Des Moines's 10,395 foreign-born citizens, 7,176, or 69 percent, had emigrated from northern or western Europe. The city also had a growing immigrant population of eastern and southern Europeans, including 1,408 Russians and 932 Italians. U.S. Bureau of the Census, Thirteenth Census of the United States: Population (Washington, DC, 1913), 2:636-37, 617; Special Reports: Statistics of Cities Having a Population of Over 30,000: 1907 (Washington, DC, 1910), 132.

6. Des Moines Register and Leader, 13 September 1906.

7. Des Moines Register and Leader, 18 November 1905. Galveston, Texas, adopted the first commission government in 1901, following a disastrous hurricane on 8 September 1900 . Although the death and destruction caused by the hurricane lent urgency to efforts to reform the city's government, according to Bradley Rice, "charter reform had been on Galveston's agenda for some time," at least since 1891. Rice, Progressive Cities, 3-4. 
Des Moines's business and professional leaders embraced the idea of commission government and quickly formed a committee to promote it. By January 1906, Berryhill and attorneys W. H. Baily and John Read had a draft charter ready to present to the Iowa legislature. Des Moines legislators Cassius Dowell of the Senate and Horace Teachout of the House introduced the legislation on January 26, but the bill was reported unfavorably in both chambers. The Register and Leader reported that a joint meeting of Senate and House Committees on Cities and Towns had "practically laughed [the bill] out of the legislative committees. ${ }^{\prime \prime}$ Although the defeated charter included at-large elections, provisions for recall, and mandatory submission to the voters of any appropriation ordinance, or franchise to "occupy or use the streets, highways, bridges or public places in the city for any private purpose," direct democracy provisions such as the initiative and referendum were absent. Undaunted by defeat, proponents of the commission plan continued to link municipal reform with the booster movement and in the fall of 1906 again began to extol the virtues of centralized government.'

The system of government these reformers wished to replace consisted of a mayor and nine aldermen, one elected from

8. 1906 Iowa Senate Journal, 145, 454; 1906 Iowa House Journal, 210, 534; Des Moines Register and Leader, 18 March 1906; Rice, Progressive Cities, 35. According to Rice, many of the legislators who opposed the measure felt the bill represented "special legislation for Des Moines." In addition, legislators were unsure that sufficient public sentiment existed for a change in government structure. Ibid., 36. See also John F. O'Connell, "Des Moines Adopts the Commission Form of Municipal Government" (M.A. thesis, Drake University, 1975), 53-55.

9. John J. Hamilton, The Dethronement of the City Boss (New York, 1910), 235, 241; the entire text of the defeated charter is on pp. 231-48. See also Rice, Progressive Cities, 36. Hamilton, who played a prominent role in both the commission government contest and the subsequent municipal election, enjoyed a remarkable career. Described in an obituary as "an aggressive and talented man," he had interviewed President Rutherford B. Hayes in 1878 on the "race problem." Following the interview, Hamilton walked from Washington to Richmond, Virginia, "making inquiries and investigations upon condition of the negro race." In 1879 he began his newspaper work and Republican Party political activity; by 1883, he owned an interest in the Des Moines News. In 1904 he retired from the paper and became economic editor of the Iowa Homestead. In 1911 he moved to Pasadena, California, where he served on the city's charter revision commission, board of education, and city commission. He continued writing political commentary until his late eighties, and died on his ninety-third birthday, 10 November 1947. Annals of Iowa 29 (1948), 327-28. 
each of the city's seven wards and two elected at large; citywide elections also determined the city treasurer, auditor, police judge, and solicitor. Much of the city's executive power resided in the hands of the Board of Public Works, which was appointed by the mayor and approved by the city council; and "quasiindependent" boards ran the police and fire departments, "placing many of the municipality's functions beyond the direct control of the voters." The city's leading citizens were discontented with this "complicated arrangement"; in late 1905 the Register and Leader claimed that "a general feeling of dissatisfaction over the present management of municipal affairs ... has been manifest for some time." Proponents of commission government believed that structural change would streamline and cleanse municipal government; "good government," they assumed, "would necessarily flow from efficient machinery."

Politically, the Republican Party dominated Des Moines in the decade before 1907. Between 1896 and 1906, Republicans won at least a majority on the council at each election, including sweeps in 1902 and 1904. Republicans also won five of six mayoral races, losing only in 1900, when a group of dissident Republicans combined with the city's Democrats to support Democrat J. J. Hartenbower in his successful campaign against Republican incumbent John MacVicar. MacVicar's support of public ownership of municipal utilities had earned him the enmity of many of the city's Republicans who claimed that he behaved politically more like a Democrat than a Republican. ${ }^{11}$

Fiscally, the Republican-controlled city government ran in the black from 1905 to 1908 . The treasury's cash surplus increased from $\$ 324,736$ on March 31, 1906, to $\$ 392,988$ on March 31, 1908. Among the 47 American cities with populations between 50,000 and 100,000 in 1907, Des Moines ranked tenth in population, but fifth in per capita spending for education, sev-

10. Des Moines Register and Leader, 9 November 1905; Rice, Progressive Cities, 34, xi.

11. Des Moines Leader, 7 April 1896, 29 March 1898, 27 March 1900; Des Moines News, 27 March 1900; Iowa State Register, 1 April 1902; Des Moines Register and Leader, 29 March 1904, 28 March 1906; Johnson Brigham, Des Moines: The Pioneer of Municipal Progress and Reform of the Middle West, 2 vols. (Chicago, 1911), 1:379. 
enth for streets, ninth for sanitation, fifth for fire protection, and twenty-ninth for police. ${ }^{12}$ Because nearly 80 percent of the city's expenditures went toward education, maintenance and improvement of the city's infrastructure, and public protection, and because the city government ran economically, it is difficult to credit the Des Moines reformers' claims of "inefficiency." Although the pro-commission press printed frequent stories of governmental inefficiency in areas such as street cleaning and streetlight maintenance, complaints about these ineffective services came mainly from the more affluent areas of the city's west side. While it appears that the government managed the city's finances economically, residents of the city's upper-class neighborhoods apparently felt that the city was paying insufficient attention to their needs. ${ }^{13}$

Is it possible that these reformers, who were vague about the sources of their discontent, found reason for dissatisfaction in a corrupt and ineffective police department? Shock at the proliferation of saloons, prostitution, violence, and theft might be sufficient cause to call for a change in government. But the Des Moines police department seems to have served the city honestly. Des Moines's crime statistics indicate that the city was safe but somewhat disorderly. In 1907 Des Moines police made 8,188 arrests, ranking fourth among their city-size cohort. However, more than 90 percent of those arrests were for offenses against society: crimes against chastity, drunkenness, disorderly conduct, vagrancy, and gambling. The city ranked twenty-first in its city-size cohort in crimes against persons and twentieth in crimes against property, while only Oakland, California, had more arrests for offenses against society. Des Moines ranked fifth in arrests for gambling among the 47 cities of 50,000 to 100,000 and eighth in total arrests for drunkenness. However, it ranked twenty-ninth in percentage of arrests for drunkenness relative

12. U.S. Census Bureau, Special Reports: Statistics of Cities Having a Population of Over 30,000: 1905 (Washington, DC, 1907), 131; and Special Reports: 1907 (Washington, DC, 1910), 143, 354, 364, 367, 370.

13. For accounts of these complaints, see Des Moines Register and Leader, 3 October 1905 and 23 November 1906; Des Moines News, 27 July 1905, 15 January, and 24 March 1906; O'Connell, "Des Moines Adopts Commission Government," 17-21. 
to other crimes, in large part because it was so diligent in enforcing chastity laws. Only four cities of any size nationwidePittsburgh, Kansas City, Philadelphia, and St. Louis, all with populations in excess of 185,000 -had more arrests for crimes against chastity; only Salt Lake City had more arrests per capita for such crimes. New York, with a population 50 times larger than Des Moines, reported 113 fewer arrests for crimes against chastity, while Chicago, with a population 26 times larger, had seven fewer arrests than Iowa's capital. Thus, Des Moines's police seemed diligent in their attempts to control both prostitution and gambling, two traditional sources of police corruption. ${ }^{14}$

When many of Des Moines's reformers talked about corruption, they meant political corruption: bribery of voters, ballot box stuffing, and profitable arrangements between city officials and contractors or public service corporations. Despite their emphasis on rampant city hall graft, however, the men who drafted the charter codified as misdemeanors offenses such as bribery, ballot box stuffing, and kickbacks from contractors or public service corporations. The draft charter prescribed light punishments for public malfeasance, a curious stance in light of the reform crusade to rid the city of corrupt politics. As Samuel Hays has observed, either Des Moines's reformers "did not oppose corruption per se," or they felt that reform of the city's political structure would provide a sufficient safeguard against the political excesses of the ward system, or claims of political corruption offered a convenient rhetorical trope to use in the battle for reform. ${ }^{15}$

14. U.S. Census Bureau, Special Reports: 1907, 131-32, 410-12, 420; Douglas Wertsch, "The Evolution of the Des Moines Police Department: Professionalization and the Decline of Public Disorder Arrests in the Twentieth Century," Annals of Iowa 48 (1987), 435-49.

15. Hamilton, Dethronement of the City Boss, 92-97; Hays, "Politics of Reform," 161. Sections $5 \mathrm{a}$ and $5 \mathrm{~b}$ of the new charter prescribed punishment for election fraud, and section 13 prohibited city employees from "interest" in contracting jobs, their materials or profits, or from accepting any free passes or service from public service corporations. Election fraud was punishable by a fine of between one hundred and five hundred dollars and a jail sentence between ten and ninety days, while a conviction under section 13 carried a maximum sentence of thirty days and a fine of three hundred dollars. Hamilton, Dethronement of the City Boss, 194-95, 201-3. 
It seems that Des Moines's elites exaggerated both inefficiency in the city government and political corruption. The people of Des Moines lived in a city that educated its children, maintained the city's infrastructure, and controlled its potentially unruly elements. The streets were safe, and the city was prosperous and expanding. Although some of the city's leading citizens may have believed that corruption existed in city hall, even newspaperman John J. Hamilton, a reform spokesperson and leader, admitted that Des Moines was "not an exceptionally badly governed city under the old regime. ${ }^{\prime 16}$ How then, did reformers argue for a change in city government?

FOLLOWING THEIR DISAPPOINTMENT in 1906, Des Moines's business and professional leaders realized that a successful assault on the existing city government required a unified, press-supported effort. They began early in 1907 by building their campaign on the rhetoric of a modern, efficient, business-like city government. In January 1907 reformers had to choose between the "Indianapolis Plan" of one-man control through a strong mayor overseeing the city council, and the "Galveston Plan" of government by a commission, including a mayor and four aldermen elected at-large. Hamilton suggested a debate on the merits of the two plans and in January submitted to the Commercial Club a list of 100 men to judge the debate. The Commercial Club and Greater Des Moines Committee quickly endorsed the suggestion and expanded the list to 300 names. ${ }^{17}$

Throughout the reform campaign, the city's three largest newspapers-the Register and Leader, the Capital, and the News -embraced and articulated the reform position. ${ }^{18}$ As the debate

16. Hamilton, Dethronement of the City Boss, 92.

17. Ibid., 109-10; Rice, Progressive Cities, 37; Des Moines Register and Leader, 7 January-1 February 1907; Des Moines Capital, 8-12 January 1907.

18. All three newspapers were committed to the city's growth through the expansion of business opportunities and championed efficient, business-like methods in city government. While the Register and Leader and Capital styled themselves "progressive," Republican newspapers and supported Theodore Roosevelt in 1904, the News charted a more independent political course and frequently railed against monopolies, particularly the railroads. 
was beginning, the Register and Leader and the Capital polled their readers to determine the level of public support for a change in city government. The Register and Leader sent letters to Des Moines's most prominent residents, asking, "Do you believe that the time is ripe for a movement for better city government in Des Moines?" and "Have you any opinion as to the course that should be pursued to secure it?" The Capital printed a ballot asking readers to vote either for or against a change in city government and to indicate whether they favored the Indianapolis or Galveston Plan. The Register and Leader claimed that 117 of 120 respondents wanted a change in government: 62 favored the Galveston Plan, while 26 supported the Indianapolis plan. According to the Capital, 606 respondents preferred the Galveston Plan, 412 the Indianapolis Plan, and only 23 desired no change. ${ }^{19}$ Following these two surveys and a meeting and debate on January 31, 1907, Des Moines's leading citizens endorsed the Galveston Plan by a vote of 106 to 27 , thus committing the reformers to a Galveston-style commission government as the cure for Des Moines' "ills."

Who were the "leading citizens" driving the commission plan? Reformers who constituted the Committees of One and Three Hundred were the cream of Des Moines society: over three-quarters of the 98 members of the Committee of One Hundred and nearly 57 percent of the men on the Committee of Three Hundred had appeared ten years earlier in the 1897-98 Blue Book listing of the city's most socially prominent residents. Thus, many of the reformers had occupied the top rungs of Des Moines society for at least a decade, and they considered themselves the city's most substantial and influential citizens. Representatives of the city's three main newspapers-editor Harvey Ingham of the Republican Register and Leader, manager Mel Uhl

19. Des Moines Register and Leader, 13 January and 1 February 1907; Rice, Progressive Cities, 38-39. The group chosen by the paper represented the city's "best" citizens. Nearly 60 percent were listed in the social register, the Des Moines Blue Book; 25 percent of the men owned businesses or were company officials, 24 percent were attorneys, 13 percent were bankers, and 13 percent worked in insurance, real estate, or construction or occupations related to the construction industry. The Blue Book of Des Moines, Iowa, 1897-98 (Des Moines, 1897); Des Moines City Directory, 1907 (Des Moines, 1907); Des Moines City Directory, 1908 (Des Moines, 1908). 
of the independent News, and owner Lafayette Young of the Republican Capital - served on both committees. Many of the remaining members of the two committees tended to be professionals, mainly physicians and attorneys, or clustered in four other occupational groups: banking, insurance, real estate, and construction and building supplies. The Committee of One Hundred included 32 professionals, 11 men in banking, 4 in insurance, 5 in real estate, and 5 in construction. The Committee of Three Hundred included 48 professionals, 35 men in banking, 26 in insurance, 17 in real estate, and 30 in construction. But whereas the Committee of One Hundred included only 11 business owners or company officers, that number jumped to 73 on the Committee of Three Hundred. Thus, businessmen committed to Des Moines's expansion formed the largest group in the enlarged committee. Using the city's press to trumpet the importance of a new government to Des Moines's growth, these men sought to effect a political reform that they believed would help spur expansion and would, incidentally, increase the profits of their businesses. ${ }^{20}$

The letters these men wrote to the paper reflect the rhetorical emphasis of the early commission campaign. Banker and business owner John Cownie believed that the city's government "should be on a purely business basis and eliminated from politics," a position endorsed by the majority of the respondents. Banker Gilger E. MacKinnon advocated electing "a business man mayor, with a business man's salary." Attorney George F. Henry wrote of the importance of "better city government" to the success of "efforts for a 'Great Des Moines.'" Several respondents mentioned the slogan of Des Moines's

20. Des Moines Register and Leader, 6 and 13 January 1907; Des Moines Capital, 8 and 14 January 1907. Information on the social and occupational composition of the Des Moines reform movement is drawn from four sources: The Blue Book of Des Moines, Iowa, 1897-98; Des Moines city directories for 1907 and 1908; Who's Who in Des Moines, 1929 (Des Moines, 1929); and biographical sketches of the most influential people in Des Moines compiled by the Press Club of Des Moines, A Newspaper Reference Work (Des Moines, 1912). Seventy-six of the 98 members of the Committee of One Hundred and 171 of the 302 members of the Committee of Three Hundred appeared in the 1897-98 social register. Many of the people on these two committees combined occupations. For instance, several attorneys and doctors worked for insurance companies or banks or served as directors of banks or insurance companies. 
boosters, "Des Moines does things," in their letters, but the fullest expression of the reformers' mix of civic boosterism and elite pretensions came from Ulysses G. Swartz, superintendent of the International Correspondence Schools. Speaking for "all the better class of citizens" with whom he came into contact daily, Swartz exhorted his fellow reformers to "push" the commission plan in order to bring about "tangible action" and to "show the world" that, indeed, Des Moines was doing things. ${ }^{21}$

These people wanted to change the structure of municipal government because they objected to yielding political control to people who shared neither their interests nor their vision of a greater Des Moines. As Samuel Hays wrote in 1964, these men were simply "dissatisfied with existing systems of municipal government ... that enabled local and particularistic interests to dominate." In contrast to the prevailing ward system, which, according to John Hamilton, "encourages a local selfishness destructive of the general, and ultimately of the local interests as well," reformers believed that at-large representation would allow the community's "common mind" to develop into "dominant public sentiment on every question pending in the community. ${ }^{\prime 22}$ Since a diffuse political system threatened the ability of business and professional elites to realize their dream of a great and growing city, they determined to "modernize" and centralize the city government.

The rhetoric of efficiency, modernization, and centralization, obscured their true goal: political control by the "better classes" of Des Moines's citizens, and, incidentally, the opportunity to shape the city's growth. In order to achieve their goal, they developed a plan to curb potential democratic excesses. They proposed to reduce the number of elected offices from thirteen to five and eliminate ward representation, making it more difficult for a person with limited financial resources to run for office since citywide electioneering would likely be more expensive than local campaigning. In addition, the charter's initiative section mandated that any ordinance passed by the council would

21. Des Moines Register and Leader, 13 January 1907.

22. Hays, "Politics of Reform," 161; Hamilton, Dethronement of the City Boss, 41, 50-51. 
become law within ten days of its passage unless opponents could secure signatures equal to 25 percent of the vote cast for mayor at the preceding election. Therefore, the most objectionable laws could be promulgated, passed by three council members (a majority), and become law unless opponents could gather about 3,000 signatures on an initiative petition within ten days. In short, Des Moines's prominent residents sought to create a system that would allow them to exercise political influence commensurate with their privileged economic status. In pursuit of that goal, democratic practices became simply an obstacle to be overcome. University of Iowa political scientist Benjamin Shambaugh, for example, argued that "commission government is the most democratic of all forms of municipal organization thus far devised" even though, he acknowledged, "the old principle of the separation of powers is ignored, and within the organization itself there is practically no provision for checks and balances." ${ }^{\prime 23}$

Pro-commission reformers obfuscated the antidemocratic potential of the charter by focusing on the purported inefficiency of Des Moines's existing government. Robert Fullerton, vice-president of Chicago Lumber and Coal and trustee of the Equitable Life Insurance Company, called the "present plan [of government] ... very defective and unbusinesslike." Attorney Joseph A. Dyer described city government as "incoherent and debilitated." One of the directors of Iowa National Bank, attorney Charles W. Johnston, wrote that commission government provided the remedy for municipal inefficiency and claimed that "all successful concerns in the business world are so managed," citing the United States Steel corporation as a "good illustration." Several reformers also mentioned the city's press as the most practical way to spread the gospel of centralized government. William G. McDougal, manager of the Armour Grain

23. At that time, Des Moines voters voted for a mayor, three aldermen (one from their district and two at large), and treasurer, auditor, police judge, and solicitor. Under the new charter, the city council appointed the treasurer, solicitor, and auditor. Rice, Progressive Cities, 34; Hamilton, Dethronement of the City Boss, 198; Benjamin F. Shambaugh, Commission Government in Iowa: The Des Moines Plan (Iowa City, 1912), 17; Citizens' Committee, "The Proposed Galveston-Des Moines Plan for City Government," A. J. Mathis Papers, State Historical Society of Iowa, Des Moines (hereafter cited as SHSI). 
Company, predicted that the "public press would be of invaluable service in educating our community," and Joseph Dyer called on the city's papers to join forces and "boost" reform "repertorially [sic] and editorially each day. ${ }^{24}$

During the early debate over the proposal, commission opponents countered by attacking the origins and ultimate goals of the Des Moines Plan as well as its antidemocratic substance. Former People's Party delegate Leonard Brown, a frequent contributor to the Iowa Unionist, called the "disparagement of City Governments" the first step toward "bringing in of arbitrary rule-the Russianizing of America in the interest of billionaire trusts and of the millionaires that own all the means of enlightenment and control of public opinion-the press." Waving the "bloody shirt," Brown described the incipient Des Moines Plan as a threat to "popular liberty," and warned that the Galveston Plan represented "the spawn of the ex-southern confederacy now playing possum. Four years of bloody war to break up and destroy freedom has not sufficed to satisfy hell-born desire!" $\mathrm{He}$ concluded that proponents of either of the two autocratic plans must be either "imbeciles or traitors." ${ }^{25}$

Two weeks later, printer Amon Blank called Des Moines's leading boosters "union wreckers" who used the booster idea as "a cloak to secretly fight labor unions." He claimed that these men, led by John Cownie and Commercial Club president Philo C. Kenyon, had refused to involve trade unionists in the booster campaign, and were attempting to destroy unionism in Des Moines by "surreptitiously . . . railroad[ing] a bill through the legislature placing this city under one man rule-the Galveston plan." Although he was confused about the nature of the two plans, Blank reminded the boosters that Des Moines's unionists were also "vitally interested in the future development of the city," and that they knew the importance of patronizing local business. Nevertheless, Blank predicted that the city's union workers would oppose "all schemes granting special privileges to a few at the expense of the many."

24. Des Moines Register and Leader, 13 January 1907.

25. Iowa Unionist, 4 January 1907.

26. Iowa Unionist, 18 January 1907. Cownie owned the J. H. Cownie Glove Company and was vice-president of the Iowa National Bank; Kenyon owned 
BY THE END OF FEBRUARY, reformers had submitted a commission government plan to the Iowa legislature. Although it was similar to the 1906 bill, the 1907 bill allowed only cities with populations greater than 25,000 to adopt commission government, and it included two direct democracy provisions missing from the 1906 proposal: the initiative and referendum. As the bill began its course through the legislature, the disparity in resources available to the respective sides became clear: while reformers disseminated their message through their powerful allies in the city's press, opponents had to petition the legislature. During the last week of February, the Seventh Ward Municipal Club, the Swedish-American Republican Club, the United Carpenters and Joiners of America (located in Des Moines), and the Hebrew Republican Club sent petitions protesting the Galveston Plan to the Senate. The Fourth and Sixth Ward Improvement Leagues, the first precinct of the fourth ward, and Local No. 441 of the Electric Railway Employees of America joined the Seventh Ward Club and the Swedish-American and Hebrew Republicans in protesting the bill in the House. The petition submitted by the Hebrew Republican Club called the commission plan, now known as the Des Moines Plan, "undemocratic" and "pernicious," "a subterfuge to deceive the people," and claimed that the plan took "away from the common people the right to choose their representatives in city affairs." The petitions proved ineffective, as the bill passed the legislature and was signed into law by Governor Albert Cummins on March 29, 1907..7

Having secured the legislation necessary to authorize cities to choose the commission form of government, commission proponents now had to secure sufficient names on a petition to place the measure on the local ballot. On April 6, the Nerws reported that former Democratic congressman Walter H. Butler, attorney Francis R. Korns, insurance broker Henry H. Lantz, attorney Sidney Dillon, dentist W. N. Heaton, real estate broker

the non-union Kenyon Printing and Manufacturing Company. According to the News, Cownie's business had 133 employees, while Kenyon employed 45 to 50 workers. Des Moines City Register, 1907; Des Moines News, 12 May 1907.

27. Des Moines Register and Leader, 3 and 13 February and 30 March 1907; Des Moines News, 30 March 1907; 1907 Iowa Senate Journal, 374, 385-86, 439, 522; 1907 Iowa House Journal, 473, 492, 602-3, 885. 
Archibald Stewart, and land developer Buffon Walker would coordinate the petition drive. In the next two days, 5,000 voters signed the petition. During the petition drive, reformers left nothing to chance. In order to create the appearance of a mass movement, they decided on "promiscuous" soliciting, because "it would make it apparent to the much solicited man that here was something doing." State Librarian and banker Johnson Brigham exhorted his allies to "din the ears of Des Moines voters" with the question "have you signed the petition?" 28

On April 5, News editor E. A. Nye warned banqueting commission proponents discussing the petition campaign that he found "much prejudice against the new plan" among the city's working men. At the close of Nye's remarks, business owner Frank Evans emerged triumphantly from the kitchen of the Shrine temple with a petition signed by ten waiters, and announced, "I thought I'd find out about that. Everyone of those ten men out there signed for a change in the city government and they are what Mr. Nye has called the 'salt of the earth.'" African-American attorney S. Joe Brown rose amid the applause to observe that "most of those out in the kitchen are colored people. ${ }^{\prime 29}$ When employers used similar tactics during the petition drive, the Iowa Unionist charged that they were using intimidation to gather signatures. The labor weekly reported that when Des Moines laborers "were paid their wages, the petition for signatures was presented with these polite (?) words; 'I want you to sign that petition. ${ }^{\prime \prime \prime 30}$

Although the petition drive progressed smoothly, criticism of the plan by the city's unions and working-class leaders forced the commission discussion onto different terrain and the reformers into a more defensive posture. Des Moines's three daily newspapers continued to champion the plan while simultaneously "boosting" the city, but a shift in their rhetoric suggests a desire to appeal to a broader audience, one that might otherwise be convinced by the anti-commission critique of the plan's antidemocratic character. At a March 10 meeting,

28. Des Moines News, 6 and 8 April 1907; Des Moines Capital, 6 April 1907.

29. Des Moines Capital, 6 April 1907.

30. Iowa Unionist, 12 April 1907. 
for example, Des Moines socialists had passed a resolution claiming that "the election of aldermen by wards enables the working class to secure representatives that they could not elect at large," and calling the direct democracy provisions "fake[s] to secure the adoption of the whole villainous system." Following the successful petition drive, the Register and Leader began stressing the democratic aspects of the plan. On April 14 an article written by attorney and banker Ira M. Earle, one of the authors of the commission bill, called the Des Moines Plan "essentially a business government, 'by the people, of the people, and for the people,'" and assured readers that the plan to centralize governing power was "subject to the reserve powers to be exercised by the public directly." ${ }^{\prime \prime 1}$

Unable to match reformers' resources or coercive ability, their opponents nevertheless continued to assail the plan's antidemocratic elements. Printer D. H. Caldwell, editor of the Iowa Unionist, called the reform movement a "plot to destroy representative government," and tied it to "the attempt to destroy the power of the union labor element." Opining that at-large elections and elimination of political parties "place all power of government in the hands of a few," and were not in "the interest of organized labor," he urged workers to "oppose any system that proposes to eliminate parties and principles and thus destroy representative government." Two weeks later, the labor weekly likened the Des Moines Plan to "an oligarchic form of government, as of Venice under the Doges." ${ }^{\prime 32}$

These warnings failed to stem the momentum of the commission movement. On April 22, the News boasted that Mayor George Mattern had received a petition containing 6,032 names, more than half the number of voters in the previous election. ${ }^{33}$

BETWEEN THE END OF APRIL and the election on June 20, the three Des Moines dailies, particularly the News and Register and Leader, bombarded the city's voters with a steady diet of procommission and booster propaganda mixed with unfounded

31. Des Moines Register and Leader, 4 February, 11 March, 14 April 1907.

32. Iowa Unionist, 12 and 26 April 1907.

33. Des Moines News, 22 April 1907. 
accusations of municipal ineptitude and corruption. In midMay, the News called for the end of municipal graft and cited several examples of "old city misrule." The paper claimed that the city's coffers were always empty by April 1, a contention contradicted by the city's cash surplus of over $\$ 350,000$. The daily also claimed that the Sixth Street Bridge had cost the city over twice its initial estimate, that the unfinished library had already exceeded its estimate by $\$ 75,000$, that the spoils system resulted in "needless expense and incompetent services," and that the city's street cleaning service "has always been poorly managed and unsatisfactory." Undaunted by flimsy evidence and attenuated or nonexistent connections between cost overruns and city officials, the News exposé signaled another tactical shift in the commission campaign, as the exposure of ludicrous city government "graft" became a feature of pro-commission rhetoric during the final month of the campaign. ${ }^{34}$

On May 15, the News charged that "the working men have lost more money at the hands of the present administration ... than you can stack up in the council room." The paper implied that part of the money went to City Solicitor William H. Bremner and Aldermen W. H. Brereton and Wilbur Fraley, who allegedly had increased their net worth as the result of public service. On June 14, the paper printed a confession from procommission convert Alderman John L. Hamery, in which he claimed, "I have discovered my mistake. The few honest men on the council are powerless under the present system. If Des Moines would have its municipal management rectified and the corruption swept out of the city hall it will be necessary to make a radical change. ${ }^{\prime \prime 35}$ Clearly, only the voters could put a stop to this pervasive, but shadowy, municipal corruption.

34. Des Moines News, 13 May 1907. The bridge and library served as symbols of either Des Moines's political corruption or its progress. While the papers used cost overruns on the two structures to illustrate municipal corruption, in booster literature the Greater Des Moines Committee used them to symbolize the city's progress. Both were pictured in the committee's pamphlet, Des Moines Means Opportunity, as examples of the latest in up-to-date architecture and engineering know-how, two of many examples of how "Des Moines does things." Greater Des Moines Committee, Des Moines Means Opportunity (Des Moines, 1907), 15, 46-47.

35. Des Moines News, 15 May and 14 June 1907. 


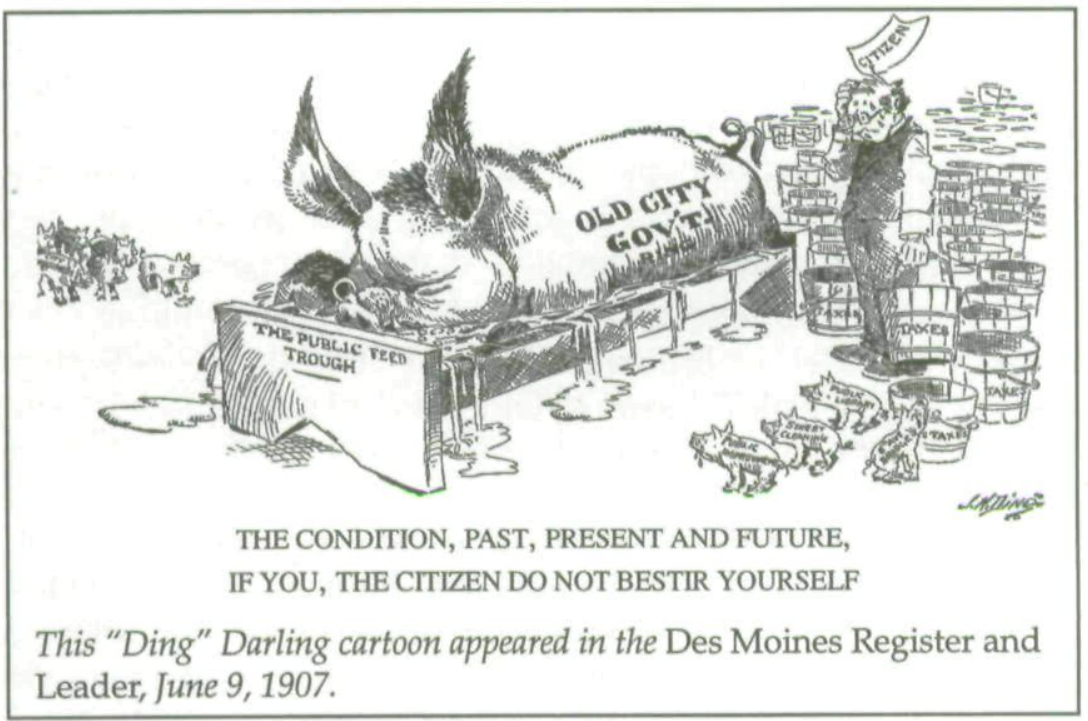

The Register and Leader chimed in with its own attacks on municipal corruption. On June 9, it printed a cartoon showing a perspiring and quizzical citizen holding a slop bucket labeled "TAXES" and staring at an immense pig labeled "OLD CITY GOV'T. RING" wallowing in an overflowing "PUBLIC FEED TROUGH." Waiting hungrily and vainly for their share of the food were piglets on both sides of the trough. On one side were piglets representing uncompleted city business; on the other, four piglets representing examples of graft: the street cleaning, library, and bridge scandals reported in the News and an obviously hungry piglet labeled public improvements. On June 18, the Register and Leader reported that the "City Hall Ring" admitted that thousands of fraudulent voters were illegally on the city's voter registration books. As in the case of the cost overruns and Hamery's claim of corruption in the city government, the story named no names; the fraudulent voters appeared as if by magic, placed in the books by an unknown hand and discovered in the nick of time by the paper, thereby preventing the theft of the election and the frustration of the popular will "by designing persons." ${ }^{136}$

36. Des Moines Register and Leader, 9 and 18 June 1907. See also editorials, ibid., 18 and 19 June 1907; and Des Moines Capital, 8 and 10 June 1907. 
While the papers continued to find and report instances of political corruption, reform spokespersons appeared at neighborhood meetings prior to the election to address their opponents' antidemocracy accusations. On June 5, Walter Butler assured a meeting of fifty men at Sixth and Forest Avenues that the "Des Moines plan is more representative than the present system.... people's representative rights should not and would not be taken from them." The same evening, at a meeting of commission opponents at the Eighteenth Street fire station, attorney R. J. Bannister claimed that the "new plan would establish a regular star chamber system." Assistant City Solicitor W. M. McLaughlin described the new plan as "monarchial government" and predicted that its adoption would "rob the people of their representative rights." The next night, pro-commission attorney Silas Allen, at a good government meeting at Twentieth and Forest, responded directly to Bannister and McLaughlin's criticisms, calling the existing city government undemocratic, autocratic, and "directly opposed to the plan of the national government. ${ }^{\prime 37}$

The press wrapped up the campaign with paternalistic appeals to the city's African-American population, women, and workers. Each of these appeals included a warning. Together they illustrate both the disdain reform leaders held for these groups and the vision of social hierarchy the reformers embraced. On June 17, the Register and Leader printed a message to the city's 600 African-American voters. Titled "To the Negro Voters," the article urged black voters to support the commission plan because at-large elections would give them the opportunity to "vote for candidates in the east and west, north and south parts of the city." Rather than having aldermen in only two wards "who will give him a listening ear," the AfricanAmerican voter would command the respect of all potential candidates as his vote "at once becomes an integral and important factor in the election." The day following Ingham's appeal to African Americans, the News urged the women of Des Moines

37. Des Moines News, 7 June 1907 . The same edition carried a front-page story calling on working men to reject the alleged claim by Alderman J. O. Staleyalso editor of the Iowa Unionist-that he "owns" and "controls" 5,000 working men. 
to "get your man to the polls." Claiming that the "city hall gang" cleverly "denied [women] the right to vote upon the expenditure of tax money for the building of a new city hall" (a bond election to be held at the same time as the referendum on commission government), the paper urged the city's women to "administer a rebuke to the gang that disfranchised them by a stroke of the pen." Although the city's women could only "vote by proxy," they could ensure their proxy's presence at the polls. ${ }^{38}$

Finally, the day before the election business owner Angus Campbell promised the city's laborers that if the Des Moines Plan passed they would not only "find renewed demand" for their labor but that even in the event of a financial panic, the city's credit would be so good that "she could inaugurate important enterprises that would employ great numbers of her laboring people and thus in a measure turn away the calamity." Campbell urged workers to "look at the matter from the standpoint of your own welfare," and to reject the demagogues "howl[ing] from the woods about your losing your political liberties." He closed by threatening that if the Des Moines Plan went down to defeat because of "deluded working men throwing their balance of power against its adoption ... laboring men will be the great sufferers." In an unstable economic environment that would culminate in the October panic of 1907, workers ignored Campbell's warning at their peril, and it is not hard to imagine employers issuing similar warnings to workers throughout the city. In a public forum, Campbell had put the city's workers on notice: everyone who wanted to keep their job should support the Des Moines Plan. ${ }^{39}$

Thus on consecutive days, two of the city's dailies had warned African Americans and women that the new plan's defeat would perpetuate their political impotence, and threatened the city's workers that their jobs were at risk if the plan failed. Rhetorically, each appeal positioned the reformers as protective

38. Des Moines Register and Leader, 17 June 1907; Des Moines News, 18 June 1907. 39. Des Moines Register and Leader, 19 June 1907. The Panic of 1907 is discussed in numerous works. For a brief but interesting interpretation of its effects on labor and local reform and on perceptions of the wealthy elite's right to rule, see Nell Irvin Painter, Standing at Armageddon: The United States, 1877-1919 (New York, 1987), 212-15. 
Percentage of Voters Rejecting the Des Moines Plan, by Ward, Compared to Percentage of Working-Class Residents in Each Ward

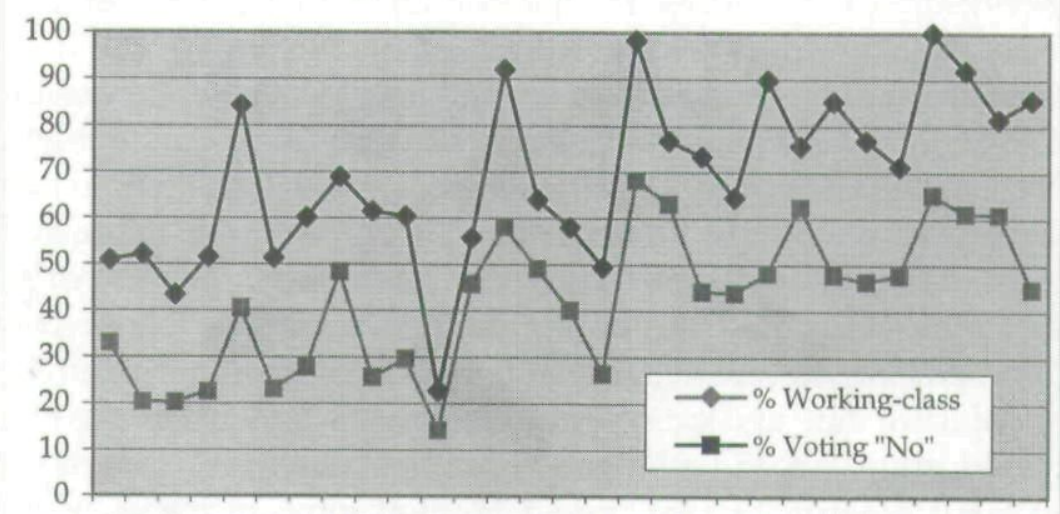

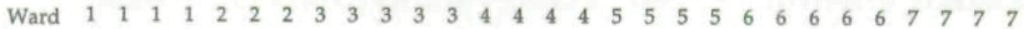

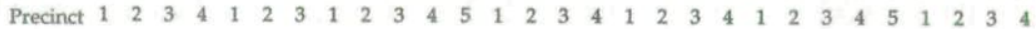

Note: Wards were numbered west to east, with the first ward in the extreme west and the seventh ward in the extreme east. Wards $1-4$ were on the west side of the river; wards 5-7 were on the east. The classification of working-class residents follows John F. O'Connell, "Des Moines Adopts the Commission Form of Municipal Government" (M.A. thesis, Drake University, 1975), 99-110, 173-76. O'Connell used statistical sampling to create a class profile of Des Moines's seven wards. The 1907 election results demonstrate the salience of class in the commission election. According to O'Connell, the city's upper class lived primarily in precincts two, three, and four in the first ward. These three precincts ranked third, second, and fourth in support for commission government, with percentages ranging from 77.4 to 79.7. The city's poorest residents, as well as large numbers of foreign-born residents, resided in the fourth and fifth wards. The seventh ward, where more than 60 percent of voters rejected the proposal, contained the highest percentage of "average working-class people."

parents of their potentially willful children and implied that if the children behaved properly, they would receive parental approval and possible material rewards; if they failed to heed parental admonitions, they faced an uncertain future devoid of parental protection.

On June 20, 1907, Des Moines voters, by a 60 percent majority, approved the "Des Moines Plan." The election results exposed the city's class divisions, as the measure lost in the city's eastside wards while westside voters approved the plan overwhelmingly. Voting patterns reflected a close correlation be- 
tween the percentage of working-class residents and rejection of the proposal (see chart). ${ }^{40}$ In the glow of triumph, the Register and Leader called the vote "a victory for the whole of the city." While the Register and Leader congratulated the voters, the Capital celebrated the triumph of business opportunity. Crediting the Greater Des Moines Committee and the city's press for the victory, Lafayette Young editorialized that the committee "by its wise action has added nearly fifty per cent to the value of real estate and as a consequence has added to the general prosperity, helping every man, woman and child." Young saw the election as a "vote of confidence to the three hundred business men who spent their time and money in attempting to secure a more efficient form of city government." He also stressed the importance to the drive of a "united press." Young promised that both the Greater Des Moines Committee and the Commercial Club would do their "part in the future as in the past," but warned that all their good works would come to naught unless "wise, unselfish and patriotic men" were elected commissioners. ${ }^{41}$

THE CAMPAIGN to elect their own candidates proved to be a critical weakness in the reform strategy. Eight days after the election, the Unionist gave fair warning that "the labor element can put a crimp in the aspirations of many politicians and boodeling [sic] business men who have been mentioned by the newspaper combine for czarships. ${ }^{142}$ To prevent a successful assault on the second part of their strategy, reformers attempted valiantly to keep their coalition intact. Unfortunately for them, the alliance cracked, as several interrelated factors contributed to the inability of the city's "better" elements to elect the men of their choice: resistance to the businessman's ticket supported and championed by the reform press; the defection of the News, destroying the press unity that had been so effective in the commission campaign; and the candidacy of popular ex-mayor John MacVicar,

40. Hays, "Politics of Reform," 162; Des Moines Capital, 21 June 1907; Des Moines Register and Leader, 21 June 1907; O'Connell, "Des Moines Adopts Commission Government," 99-110, 173-76.

41. Des Moines Register and Leader, 21 June 1907; Des Moines Capital, 21 June 1907.

42. Iowa Unionist, 28 June 1907. 
whose pivotal presence in the race for commissioner would undermine the efforts of the business leaders who sought to control city politics.

After the commission charter survived a constitutional challenge, reform leaders faced the task of electing their men to run the new system. As Lafayette Young's post-election comments made clear, reformers considered the election of the right kind of men to run the new government the ultimate goal of their scheme to refashion municipal politics. The new charter provided for an open primary to be held two weeks before the regular election. Any qualified voter could appear on the primary ballot by submitting a statement of candidacy supported by a petition attesting to the candidate's character and judgment signed by 25 qualified electors. Following the primary election, the two mayoral candidates and the eight council candidates with the highest vote totals would advance to the regular nonpartisan election. The simple filing procedures resulted in 71 men declaring their candidacy for the five seats on the commission. ${ }^{43}$

The men in control of the reform campaign realized the importance of unity in the upcoming campaign, but internal squabbling eventually destroyed the powerful alliance between the reformers and the daily newspapers. Letters exchanged between John Hamilton and John MacVicar reveal the machinations of the reform leaders and demonstrate how their coalition fractured under the stress of choosing the right candidates. On October 18, 1907, Hamilton told MacVicar that "Harvey Ingham read the riot act to me on a street corner today" and warned him that the Register and Leader editor "incidentally gave notice to you, through me, that unless you come in with the rest of the Des Moines plan supporters and help agree on a ticket, he will give you a fight such as you never experienced in all your life."14

In mid-November, Hamilton described the difficulties reform leaders were having in holding their movement together. At a meeting at the westside Grant Club, bankers Homer Miller and John Cownie, attorneys Ira Earle and Sidney Dillon, news-

43. Rice, Progressive Cities, 49. The Iowa Supreme Court declared the commission plan constitutional on 18 February 1908. Shambaugh, Commission Government in Iowa, 29-31.

44. John J. Hamilton to John MacVicar, 18 October 1907, MacVicar Papers, SHSI. 
paper men Harvey Ingham, Lafayette Young, and Gardner Cowles, businessmen Eugene Waterbury, James Hill, and James Olmsted, construction company president Edward Crellin, and insurance man James Van Evera, discussed tactics for the upcoming election. They agreed that "there must be a labor representative on the slate, but that [State Trades' Council president Al] Urick would treat as a 'traitor' any man who was put forward." Hamilton reported that Ingham rejected the suggestion of attorney J. M. Parsons to let the situation develop without "private manipulation." The editor told the group, "this time we must act together and put the new law in the hands of its friends." Banker J. W. Hill assured the group that the "three dailies had promised him and others that they would support the ticket selected by the [Committee of] 300." The meeting adjourned after deciding to appoint a committee of seven to "canvass the situation as to candidates," and admonishing the attendees to "not reveal what was done to outsiders. ${ }^{\prime 45}$

Just five days later, Hamilton reported to MacVicar that Billy Hale, the editor of the News, might desert the alliance. Excluded from the insider deliberations of reform leaders, Hale assured Hamilton that the News "is not tied up in any hard and fast ticket," that the daily would "retain its independence," or perhaps "select its own ticket." Hale's subsequent defection made a prophet of MacVicar, who on 18 November had predicted that "it will not be possible to get a slate through the Committee of 300 without a serious split."

Reformers particularly feared a potential MacVicar candidacy. Although one prominent reformer, Robert Fullerton, considered him honest and concerned about "everybody's interests and rights," the leading clique worried that they would be unable to control him and desperately tried to keep him out of the race. Despite MacVicar's support of the commission plan, John Hamilton wrote that most of the leaders of the movement regarded the ex-mayor as a "firebrand" whose "strong personality" would undoubtedly dominate any ticket he was part of,

45. John J. Hamilton to John MacVicar, 15 November 1907, MacVicar Papers, SHSI.

46. John J. Hamilton to John MacVicar, 20 November 1907; John MacVicar to John J. Hamilton, 18 November 1907, MacVicar Papers, SHSI. 
and therefore "tabooed his name from the start." ${ }^{47}$ In late October MacVicar informed City Treasurer John B. Lucas that he had "been served with due notice by certain editors in Des Moines that if I refuse to come in and help elect a ticket they shall name, I will be hammered into the earth." He also told Lucas that he had "absolute proof" that Young and Ingham had made electioneve threats toward the public service (primarily street railroad) corporations that "got them to lay down on their fight against the Plan. . . . I have a curiosity to know just what these two newspaper men promised in return for supporting the fight. I believe I know, but am not absolute [sic] sure. ${ }^{\prime \prime 4}$ MacVicar never described his "absolute proof" or the nature of the threats, but in a letter to Walter Butler he charged that the two newspaper men had engaged in political log-rolling, securing the support of the public service corporations in exchange for a promise to nominate candidates "acceptable to the public service corporations." According to Rice, keeping MacVicar "off the commission" embodied the "key to the agreement," because the franchise owners apparently considered the mandatory referenda on public franchises in the Des Moines Plan a lesser evil "than the possibility of a municipal takeover that MacVicar might lead."

Two weeks later, MacVicar wrote to John Hamilton, warning him to "be very careful whom you ally yourself with, particularly in any selection of candidates." He cautioned that "the next fight will have to be along different lines from former campaigns. The business interests must be looked after and they are liable to be very active." MacVicar saw Young and Ingham as potential problems, predicting that the Register and Capital would "try a ticket. . . . One thing they have in mind is to capture the union labor vote, and this will be done by false pretenses. I hope these boys won't be fooled." He suggested that if he and Hamilton could prevent the News from joining the "scheme on the part of the Register and Capital to maintain the

47. Hamilton, Dethronement of the City Boss, 161.

48. Robert Fullerton to [John] Hamilton, 9 December 1907, and John MacVicar to John B. Lucas, 25 October 1907, MacVicar Papers, George M. Sheets Collection of Iowana, Special Collections, University of Iowa.

49. John MacVicar to Walt Butler, 25 October 1907, MacVicar Papers, SHSI; Rice, Progressive Cities, 44-45. 
role of dictator ... they won't do much harm. ${ }^{\prime 5^{50}}$ Thus, in addition to illuminating the political infighting among Des Moines's reformers, MacVicar echoed some of the same concerns labor unions had expressed about the autocratic potential of commission government.

As November turned into December, Hamilton reported that opposition to MacVicar was hardening. Despite the poor performance of "Harvey's machine," Hamilton cautioned MacVicar that "the men who control public opinion in this town are now largely against you," and that a great deal of "hard, personal work" would be necessary to "neutralize the hostility that has been worked up against you among the business and professional men." ${ }^{\prime 51}$

Finally, reform leaders of the newly expanded Committee of Five Hundred decided on five candidates. Their "Citizen's" or "Des Moines Plan" ticket included businessman and incumbent at-large alderman Eugene Waterbury for mayor, and attorney Henry C. Evans, college professor James R. Hanna, land developer and lumber company owner Buffon S. Walker, and coal company owner Charles S. Worth for city council. Opponents quickly dubbed this group of men the "silk sox ticket" or the "slate." All of the candidates belonged to social register families and possessed the requisite business or professional pedigrees, reflecting the reform belief that the "best citizens" of the city should govern. ${ }^{52}$ Along with the reform slate, a dizzying variety of other combinations emerged during the election.

50. John MacVicar to John [Hamilton], 7 November 1907, MacVicar Papers, Sheets Collection.

51. John J. Hamilton to John MacVicar, 30 November, 9 and 10 December 1907, MacVicar Papers, SHSI.

52. Hamilton, Dethronement of the City Boss, 161; Iowa Unionist, 14 March 1908; Rice, Progressive Cities, 49. According to Johnson Brigham, MacVicar enjoyed considerable support among the Committee of Five Hundred. In January committee members participated in a referendum to select their candidates for the upcoming election. Ira Earle received 46 votes for mayor, with MacVicar finishing third among the ten vote-getters. For the council, MacVicar, with 72 votes, finished first among the 28 men who received votes. Brigham, Des Moines, 1:402-3.

53. Competing against the "Des Moines" slate were the "Democratic slate," "City Hall Slate," "Prohibitionist's Slate," "Scratcher Slate," and the "Civic League Ticket." Des Moines Register and Leader, 8 March 1908; Des Moines Demo- 
While the Des Moines Plan ticket attracted little support from labor, the News led the opposition with a populist assault on the "slate" candidates. Before the nonpartisan primary, the paper declared that the ticket should be called "the Des Moines Corporation ticket," and accused Young and Ingham of promising the public corporations that "John MacVicar would not be given a place on the first board of councilmen." According to the News, Young and Ingham engaged in fraud when they ignored MacVicar, contrary to "the wishes of the majority of their own committee," and when they urged the people "to pay no attention to the part which the corporations played" in the selection of their candidates. ${ }^{54}$ The News consistently provided a powerful public forum for opponents of the "slate," a forum that had not existed during the 1907 commission campaign.

On March 16, four of the five Des Moines Plan candidates survived the primary election, but they were obviously in trouble. According to the Register and Leader, "if there is to be a general rallying of all the forces of opposition it is apparent that they [the Des Moines Plan candidates] will not be elected." Indeed, police court judge and real estate broker Adaniram J. Mathis had garnered 2,000 votes more than Des Moines Plan mayoral candidate Waterbury. Of the three successful council candidates, only one, fourth-place finisher Charles Worth, ranked in the top four. Much to the chagrin of Ingham and Young, John MacVicar proved the most popular candidate, attracting 6,399 votes, followed by first ward alderman John Hamery, and Deputy Sheriff J. Wesley Ash. More ominous than the vote totals were the ward results. The "Des Moines Plan" candidates attracted little support outside the affluent first ward. About 25 percent of Waterbury and Worth's support came from that ward, which also provided nearly 29 percent of Hanna and Walker's support. ${ }^{55}$

With little time until the regular election, the final two weeks became a contest between the four remaining members of the

cratic Chronicle, 6 and 20 February 1908; Iowa Unionist, 14 March 1908; O'Connell, "Des Moines Adopts Commission Government," 129-30.

54. Des Moines News, 9 March 1908.

55. Des Moines Capital, 17 March 1908; Des Moines Register and Leader, 18 March 1908. 
"slate" and an alternative group of candidates backed by a variety of groups. Police Court Judge Adaniram Mathis opposed Waterbury for mayor; contractor and alderman-at-large William Brereton and city assessor Charles Schramm rounded out the council field. The "Des Moines Plan" ticket of Waterbury, Hanna, Walker, and Worth refused to appear with other candidates, as they had during the primary campaign, underscoring the elite nature of the four candidates and giving credence to their opponents' attacks on their autocratic potential. ${ }^{56}$ In contrast to the commission election, opponents of the elite ticket possessed a public voice in the News as well as an alternative not present in 1907. Rather than defending an existing political system, the anti-Des Moines Plan forces offered attractive options, for middle-class as well as working-class voters, to the "slate" candidates.

While the Register and Leader and Capital endorsed the elite ticket, the Iowa Unionist endorsed Hamery and Ash, in addition to giving warm support to Mathis and Schramm. Although not opposing MacVicar, the Unionist questioned the sincerity of his pro-labor stance and asked why the News, whose political columns MacVicar controlled, ignored "Wesley Ash-labor's recognized candidate $?^{\prime{ }^{57}}$ For its part, the News endorsed MacVicar, Schramm, and Hamery, opposed the entire "Citizen's" ticket, and turned its strident rhetoric on the elite candidates, accusing them of fraud in their election expense statements. At a March 27 labor meeting, printer Edward Campbell called the expense statements a "two-faced, point blank lie," and claimed that he had received many "circulars and other literature through the mail boosting the silk sox candidates. ${ }^{\prime \prime 58}$ Thus, the political rhetoric had come full circle from 1907, as the reformers now stood accused publicly of the kind of questionable politics their system and their candidates opposed and would ostensibly eliminate.

As the campaign concluded, the Register and Leader implored the city's voters to support the elite candidates. In contrast to the appeals that had marked the final days of the com-

56. Rice, Progressive Cities, 49.

57. Iowa Unionist, 28 March 1908.

58. Des Moines News, 28 March 1908. 
mission campaign, the daily tried to cajole voters into realizing the importance of the right candidates to the success of the new government. Harvey Ingham timidly asked, "Is two years too much to discover whether business methods applied to city affairs will bring about the results business methods bring about in private affairs?" The editor, on the eve of seeing his political vision destroyed by a recalcitrant electorate, called Waterbury, Walker, Hanna, and Worth, "clean men, ... young men, ... successful men ... [who] know what it is to struggle for what they get ... who can be relied upon to do what they say." Juxtaposed with Ingham's anxiety stood the confidence of D. H. Caldwell's Iowa Unionist. Speaking for the laboring men of Des Moines, Caldwell asserted that labor "claimed for herself the right of representation on the commissions to be selected-has votes to determine the matter her own way." Calling on workers to elect Ash and Hamery, the weekly left the other three choices up to each voter's conscience. Drawing on the same rhetoric it had used to oppose the commission plan, the labor paper simply asked for representation on the new council, not for the control reformers sought. ${ }^{59}$

On March 30, 1908, voters elected Mathis mayor, and MacVicar, Ash, Schramm, and Hamery to the council. Mathis received 60 percent of the vote and enjoyed a nearly 4,000-vote advantage over Waterbury. In the council election, the Des Moines Plan candidates finished fifth, sixth, and eighth in the eight-man field. Worth, the fifth-place finisher, received 1,600 fewer votes than Schramm, who finished fourth. MacVicar, with nearly 10,000 votes, proved the most popular candidate in the field. Waterbury won only 5 of 29 precincts, 3 in the first ward. On the east side of the river, he drew only 28 percent of the vote. The other Des Moines Plan candidates also fared poorly on the east side, Worth finishing sixth, Hanna seventh, and Walker eighth. Ash, who finished second by 1,600 votes to MacVicar, outpolled the former mayor in the working-class wards by 93 votes. Even in the first ward, Waterbury won only 54 percent of the vote, while Hanna finished fourth, Worth fifth, and Walker eighth in the council race. Thus, as Bradley Rice points out, the

59. Des Moines Register and Leader, 30 March 1908; Iowa Unionist, 28 March 1908. 
1908 election did not necessarily represent a "repudiation of the new system." Instead, Des Moines's voters, particularly working-class voters, repudiated the people chosen by the city's elites to head the new government. ${ }^{60}$

IN DES MOINES between 1905 and 1908, a spirited attack by working-class spokespersons on the antidemocratic potential of commission government bared the intentions of a small group of businessmen to restructure city government to enable them to shape Des Moines's political and economic future. Workingclass voters constituted the largest group opposed to the commission plan, but the entire city participated in the defeat of the ticket selected by reform leaders. Thus, while failing to save a ward-based direct representation system, Des Moines's workers and their leaders managed to battle their opponents to a draw by winning a place in the new government. Although the city's voters indicated in 1907 that they preferred a more centralized form of municipal government, less than a year later they sent a clear message to reformers that they would not submit to elite control. Reformers tried to reformulate their rhetoric to appeal to a wide audience, but their hand-picked candidates engendered little enthusiasm among middle-class and working-class voters. In 1908 Des Moines's voters shattered the elite dream of a business-controlled government, exposed the limits of reform ideology, and signaled the city's "leading citizens" that they preferred more political control than reformers were willing to offer.

60. Des Moines Capital, 31 March 1908; Des Moines Daily Register, 31 March 1908; Rice, Progressive Cities, 50. Commission government in Des Moines lasted until 1949, when it was replaced by the city manager system. Rice, Progressive Cities, 109. The charter legislation, as amended in 1909, made 19 Iowa cities eligible for charter status. Between 1908 and 1911, seven of them-Des Moines, Cedar Rapids, Keokuk, Burlington, Sioux City, Marshalltown, and Fort Dodgeadopted the commission plan. Shambaugh, Commission Government in Iowa, 29. 
Copyright of Annals of Iowa is the property of State of Iowa, by \& through the State Historical Society of Iowa and its content may not be copied or emailed to multiple sites or posted to a listserv without the copyright holder's express written permission. However, users may print, download, or email articles for individual use. 